James T. Palmer

\title{
Apocalyptic Insiders? Identity and Heresy in Early Medieval Iberia and Francia
}

Apocalyptic traditions supplied a conceptual repertoire that was used by writers in the early Middle Ages to delineate different senses of Christian identity. In particular, fear of heresy was an important catalyst for thinking about religious communities in apocalyptic terms, as writers sought to identify their community or views with the elect within the Church. In this paper, three case studies are examined: the Adoptionist Controversy in the eighth century, the case of the Córdoban martyrs in the mid-ninth century, and the so-called Chronica Prophetica of 883. These highlight different apocalyptic dynamics, as Christian writers in Iberia and Francia argued for their particular views on religious orthodoxy against other Christians, while engaged with perceived challenges from Islam - all while believing that any corruption to orthodoxy opened the way for Antichrist. The cases remind us that, however we might want to generalise about a "Western apocalyptic tradition", the success of apocalyptic ideas often lay in their flexibility to be useful in response to a variety of situations.

Anxiety about apocalyptic outsiders and alterity played an important role in early medieval Christian thought. Prophesied punishment for sin from the North in Ezekiel and Jeremiah, combined with the threat of assault from Gog and Magog in Revelation, meant that many invaders of the early medieval West generated fears about the End Times. ${ }^{1}$ To think in such terms is, of course, also to posit a sense of being an insider that contrasts with the groups outside salvation. There was a sense of Christian collectivity, sometimes explicitly called sancta ecclesia, the Holy Church, which people identified with to make sense of their difficulties in life and their hopes for salvation in the future. ${ }^{2}$ Scripture was clear: the community would struggle and be challenged. This apocalyptic-framed identity was not without considerable complexity, as many people followed Jerome and Augustine in believing that Gog and Magog were the enemies within - namely heretics, who looked and sounded as if they were real Christians, but who were really leading people astray. Such ambiguity raises important questions about how people negotiated identities in relation to apocalyptic thought.

\footnotetext{
1 For an overview of this theme see Palmer, "Apocalyptic Outsiders and their Uses in the Early Medieval West," 307-320.

2 De Jong, “The State of the Church and Early Medieval State Formation,” 214-254. 
Both apocalypse and identity-formation are situational. ${ }^{3}$ What we mean by this, is that people actively appropriated ideas from a spectrum available to them to respond to and maybe shape specific processes. The result is that, while we can seize upon certain generalities relevant to apocalypse and identity, any given instance might subvert some of the expectations generated by the effort to generalise because of the particularities of the situation. Such lines of thought are well-developed in scholarship on ethnic identities, as demonstrated by exemplary studies by Walter Pohl and Helmut Reimitz, amongst others. ${ }^{4}$ For apocalyptic traditions, it is maybe less well investigated, not least because of debates that have essentialised what apocalypse means without allowing for much variation. As a contribution to understanding the situational variances in apocalypse, therefore, the present study will investigate the interplay of identities and End Times thought in the Iberian Peninsula after the Arab-Berber conquest of 711. Responses to the conquest itself are lost to us, but there are three valuable case studies: conflict between Frankish and Iberian churchmen in the Adoptionist debate, the conflict over the martyrs of Córdoba, and the production of the unusual Chronica Prophetica of 883. All three point towards the importance of perceptions of heresy as a key ingredient in the formation of Christian identities in the period, drawing on a crucial sense of struggle and persecution rooted in apocalyptic narratives.

The case studies naturally intersect with issues about how religious groups define themselves by theorising about the alterity of other groups. Early Christian views of Islam in the Latin West were complex, because Muslims were seen either as an imagined ethnic group (the Saracens or Ishmaelites), or as a group defined by their imagined religious beliefs (often as heretics or pagans), or both, rather than as "Muslims" in the modern understanding of people who adhere to that particular, distinct religion. ${ }^{5}$ Most constructions as we have them are unsurprisingly shot through with long-standing orientalist attitudes, often with origins that predate Islam. ${ }^{6}$ At the same time, such constructions are often part of an internal Christian discourse, designed to sharpen aspects of belief and practice or to diagnose the cause of problems, more than they are an attempt at ethnographic description or understanding of Islam. ${ }^{7}$ A central issue, as we shall see, is that talk about

3 On the circumstances of apocalypse, see Palmer, The Apocalypse in the Early Middle Ages. The classic statement of situational identity is Geary, "Ethnic Identity as a Situational Construct in the Early Middle Ages," 15-26, reprinted in Geary, Writing History, 1-18.

4 Pohl and Reimitz, eds. Strategies of Distinction. Pohl and Heydemann, eds. Strategies of Identification. Reimitz, History, Frankish Identity, and the Framing of Western Ethnicity.

5 Goetz, Die Wahrnehmung anderer Religionen und christlich-abendländisches Selbstverständnis im frühen und hohen Mittelalter, 262-265 and 352-395, mostly focusing on post-1000 examples; Tolan, Saracens; Akbari, Idols in the East; Valenzuela, "The Faith of the Saracens," 311-330.

6 Tolan, “'A Wild Man, Whose Hand Will Be against All', 513-530.

7 For a condensed survey see Palmer, "The Otherness of Non-Christians in the Early Middle Ages," 33-52 and more exhaustively Goetz, Die Wahrnehmung anderer Religionen und christlich-abendländisches Selbstverständnis im frühen und hohen Mittelalter. 
apocalyptic peoples often took place in the context of conflict between Christians, using Christian points of reference and trying to define Christianity. It was about imagination. Internal debates about identity and heresy shaped the orientalist attitudes of Latin Christians to other religious groups.

\section{Methodological Background}

Before proceeding to the case studies in detail, it is essential to review briefly some of the methodological baggage study of the apocalyptic and identities bring with them. We might start here with a simple question: was there such a thing as a singular "Western apocalyptic tradition" in the early Middle Ages from which people involved in our case studies might draw? Crude characterisations of eastern and western thought suggest that there are some common threads in each. These could include - and are not exhausted by - Augustinian agnosticism concerning the exact timing of Judgment Day, attachment to particular calculations of the age of the world, an ambiguity of attitude towards the resonance of events in Jerusalem or Constantinople, limited interest in visionaries, and localised developments in thinking about purgatorial states or the biography of Antichrist. Most of these were affected in some way by east-west communications of ideas, but they played out to generate distinctive cultural zones. ${ }^{8}$ At the same time, however, not everywhere within the western zone could identify with ideas of empire in the same way, or had real Jewish communities to encounter, or easy access to ideas coming out of Syria. Ireland, for instance, was not very much like Rome. Peter Brown has called the localised re-creations of Christian universality "micro-Christendoms," and these represent the kinds of variations on a theme we need to be aware of in our analyses. ${ }^{9}$

To get any sense of zones or micro-Christendoms we have to engage in some level of comparative history. Sometimes it is only through comparison of similar things in different contexts can we see what is distinctive, and sometimes we can only really understand what we have when we can see what it lacks in comparison to something else. A range of filters and comparisons must be applied to reveal the logic of any given example. But, as Chris Wickham insisted in his 2009 Reuter Lecture, we must tread carefully: comparative history without an explicit and reasoned basis can quickly become a collection of unhelpful or meaningless differences. ${ }^{10}$ There should be good structural grounds for comparison, which within Wickham's oeuvre includes factors such as similar size of political community. This should stand no less when engaging with sociological/ anthropological comparison across time and space. It can be valuable to look for structural similarities between

8 z.B. Meier, "Eschatologie und Kommunikation im 6. Jahrhundert n. Chr.," 41-73.

9 Brown, The Rise of Western Christendom, 15.

10 Wickham, "Problems in Doing Comparative History," 5-28. 
communities. We should be more cautious about using these insights to "fill in the gaps" in the evidence - what I have called elsewhere "Jurassic Park anthropology". ${ }^{11}$ Comparative studies illuminate less, and can indeed mislead, if the models used predetermine the outcome of analysis.

A good case study here is the use of "millenarianism" or "millennialism" as a comparative model. Finding its classic form in Norman Cohn's In Pursuit of the Millennium, and finding significant nuance in the work of Richard Landes, "millennialism" is often understood as the defining model for interpreting apocalyptic thought - a radical, subversive way of thinking which mobilises people to seek reform on Earth in ways which stand in opposition to a typically conservative and suppressive mainstream religious community. ${ }^{12}$ Millennialism can certainly be a powerful force in history. But in focusing on the radical and the transcultural, Cohn, Landes and others following them have downplayed the extent to which those mainstream religious communities had their own apocalyptic outlooks. To give one stock example: Gregory of Tours described a number of radical, disruptive holy men in the sixth century, one of whom seemed to proclaim himself the Second Coming - but the millennialist perspective misses that Gregory himself characterised these preachers as types of antichrist, prophesied in the Epistles to challenge the faithful in the End Times. ${ }^{13}$ The local evidence should always take priority over the model.

The example of Gregory already points towards some key issues in the formation of apocalyptic identities. There has, of course, been a significant scholarship on the creation and mutation of both ethnic and community identities, both of which have recently been pushed to consider what a Christian identity really meant in Late Antiquity and the early Middle Ages. ${ }^{14}$ There was always sufficient diversity in practice to ensure that there was anxiety about unity of purpose. But that unity of purpose meant that there had to be core ideas: belief in the Holy Trinity, belief in salvation, belief in Judgment Day. It is no coincidence that major theological debates in the period hinged on Christology, sin, and the apocalypse. These provided frames in which people could see their place in the world, as part of a community defined by their relationship to God and salvation. One might remember O'Leary's useful idea that apocalyptic rhetoric often hinges on explaining problems of evil, authority, and temporality. ${ }^{15}$ These were crucial ingredients of rhetoric in identity formation too, so it is no coincidence that apocalypse and identity intersected, as Wolfram Brandes and Veronika Wieser have recently shown for the last years of the

11 Palmer, The Apocalypse in the Early Middle Ages, 10.

12 Landes, Heaven on Earth.

13 Compare Cohn, The Pursuit of the Millennium, 13; and Palmer, The Apocalypse in the Early Middle Ages, 13 and 75-7.

14 Pohl, "Christian and Barbarian Identities in the Early Medieval West," 1-46.

15 O’Leary, Arguing the Apocalypse. 
Roman Empire. ${ }^{16}$ The remainder of the present essay will explore other ways in which this intersection worked, with a particular focus on the importance of heresy.

\section{Looking Inwards: The Adoptionist Debate}

The Adoptionist Debate is well-known as the last great Christological debate of Late Antiquity and the early Middle Ages, as Christians explored once again the relationship between Christ's human and divine natures. ${ }^{17}$ It presented a convenient crisis point for Charlemagne (r. 768-814) and his court, as it coincided with their efforts to bring renewed clarity to ecclesiastical and monastic order, and to develop richer overlap between religious and secular spheres. ${ }^{18}$ Moreover, Charlemagne had, since 778, developed a military presence in the Spanish March, and dealing with Adoptionism offered, as Cullen Chandler put it, "a means to establish cultural hegemony in conquered areas in an effort to integrate them into the multinational Carolingian kingdom". ${ }^{19}$ Pressures in the Iberian Peninsula were unusual, however, as many Christian communities had developed in a Muslim-dominated environment following the conquests of the early eighth century. ${ }^{20}$ The lived and the theoretical models for what it meant to be a Christian could not fail to be different for someone living in Toledo and someone living in Aachen.

The role of eschatology and apocalypticism was crucial to the Frankish perspective on Christian standards. ${ }^{21}$ Moreover, the religious standards of the Frankish kingdoms' elites were part of their self-identity. ${ }^{22}$ The Admonitio generalis of 789 , Charlemagne's first substantive reformist statement made with the assistance of Alcuin, is famous for its Old Testament allusions and restatement of conservative canon law. ${ }^{23}$ It also engaged with the theme of reform as apocalyptic drama. Indeed, this is how it ends:

We know that in the last days there will appear false teachers, as the Lord Himself foretold in the Gospel (Mt 24:11) and as the apostle Paul testifies to Timothy (1 Tim 4:1). Wherefore, most beloved, let us prepare ourselves with all our heart in knowledge of the truth, that we may be able to resist those who oppress the truth and that, by the gift of divine grace, the word of God

16 Brandes, “Gog, Magog und die Hunnen,” 477-498; Wieser, "Roms wilde Völker,” 23-50.

17 Cavadini, The Last Christology of the West. For wider context, Matter, "Orthodoxy and Deviance," 510-530.

18 Close, Uniformiser la foi pour unifer l'Empire. Kramer, "Adopt, Adapt and Improve," 32-50.

19 Chandler, "Heresy and Empire," 505-527 at 507.

20 Collins, The Arab Conquest of Spain. For a different perspective, see now Clarke, The Muslim Conquest of Iberia.

21 McKitterick, The Frankish Church and the Carolingian Reforms; de Jong, "Charlemagne’s Church,” 103-135.

22 Garrison, "The Franks as the New Israel?," 114-161.

23 Admonitio Generalis, ed. Mordek, Zechiel-Eckes, Glatthaar. 
may flourish and become general and spread to the benefit of our souls and the praise and glory of the name of our lord Jesus Christ.

Such a statement establishes a clear sense of us and them, of those united by truth and those who would oppose them with tricks and lies, defined by their standing as Judgment Day approaches. The last chapter of the Admonitio generalis that then follows serves as an illustration of how to educate people properly. It sketches an ideal sermon that emphases the nature of the Holy Trinity and Mary, that the resurrection will be bodily, that sins will be punished, and the importance of virtues. The sermon is squarely eschatological in the sense that it encourages the audience to reflect on the consequences of their actions ahead of Judgment Day. As I have suggested elsewhere, Carolingian correctio "harnessed such ideas to lend urgency to its fight". ${ }^{24}$ This is not to say that it was somehow "mere rhetoric": indeed, the power of such language often came from the perceived reality of the shortness of time.

Adoptionism provided a test case for reform. Elipandus of Toledo had already compared the priest Migetius to Antichrist for his unorthodox teachings about the nature of the Holy Trinity: "No one is your equal among heretics", he wrote, "no one is companion to you: how great the last of all, so full of the poison of all heretics, intoxicated by the poisonous filth of all heretics, clearly you are to be recognised Antichrist." ${ }^{25}$ As controversy spread concerning Elipandus's own views on the Trinity, the bishop maintained a fiery tone, and denounced Beatus of Liébana as "the ironically named Beatus, disciple of Antichrist [...] pseudo Christ and pseudo prophet” to his critic's friend Alcuin of York. ${ }^{26}$ From Oterius and Beatus's replies to Elipandus, we also discover that the bishop of Toledo had called his principal opponent a praecursor Antichristi for preaching teachings he found contrary to the faith. ${ }^{27}$ These are some of the earliest actualisations of Isidore of Seville's definition of antichrists, plural, as people who did not live according to Christ's teachings, and indeed opposed Christians, or subverted them through false teachings. ${ }^{28}$ Anxiety about such issues ran through Beatus' famous Tractatus de Apocalypsin which, like many other early commentaries on Revelation, was significantly a

24 Palmer, The Apocalypse in the Early Middle Ages, 150.

25 Elipandus, Epistola, 1.5, ed. Gil, 73: Nullus in hereticis tibi equalis, nullus tibi sodalist. Quanto cunctis nobissimus, tanto omnium hereticorum venena refertus, omnium hereticorum ceno letali inebriatus, aperte Anchristi dinosceris esse missus.

26 Elipandus, Epistola, 6.3, ed. Gil 96. (The letter begins "to the most reverend brother Deacon Alcuin, not a minister of Christ, but disciple of the most fetid and ironically named Beatus, sprung from the glorious prince in the ends of the East, a new Arius, contrary to the teachings of the venerable holy fathers Ambrose, Augustine, Isidore, and Jerome - if he turns from the error of his way, eternal greetings from the Lords; if not, eternal damnation.")

27 Beatus of Liébana and Eterius of Osma, Adversus Elipandum libri duo, 2.13-17, ed. Löfstedt 113116.

28 Isidore of Seville, Etymologiae, 8.11.20, ed. Lindsay. 
meditation on the struggles of the Church. ${ }^{29}$ Heresy naturally lent itself to apocalyptic discourse.

Alcuin himself used eschatologically-framed arguments in his attacks on Felix of Urgell, another Adoptionist. In a letter to Felix, following the bishop's condemnation at the Council of Regensburg in 792, Alcuin impressed upon his opponent the importance of the correct teachings for the unity and peace of the Church - especially as "love grows cold in the last days", a reference to Matthew (Mt. 24:12). ${ }^{30}$ In his Contra haeresim Felicis, he elaborated on this theme, which ended again with an appeal to teach the right things "up until the end of the world". ${ }^{31}$ These are not statements which depend on prophesying the end of the world. The end could not be predicted, but its shadow was cast upon all history regardless. Alcuin wrote with the assumption that the shadow could be perceived, just as Gregory the Great (590604) had done in his otherwise entirely Augustinian perspective before him. ${ }^{32}$ Ultimately, it bound together duty and judgment.

Alcuin's rhetoric did not shape the reports of the councils at which Adoptionism was debated, even though he was involved in them. We might call Alcuin's one of the "backstage publications", in contrast to the public version for wider consumption. ${ }^{33}$ The official report of the Synod of Frankfurt reports the unanimous condemnation of Elipandus and Felix as heretics in straightforward language, before continuing on to report on a variety of issues, political, economic, and ecclesiastic. ${ }^{34} \mathrm{~A}$ letter sent by bishops to Spain to announce the synod in advance is striking for the regional identities it invokes in its opening address, from "all the bishops of Germany, Gaul, and Aquitaine" (episcopi Germaniae, Galliae et Aequitaniae), to the "prelates of Hispania" (praesules Hispaniae). ${ }^{35}$ Administratively, the sancta ecclesia was a collaborative enterprise which was not blind to its regions. ${ }^{36}$ In such a context, the bishops were keen to renew unity through a "counsel of peace" and to defend the True Faith "in which [...] stands the beginning and end of our salvation". They recognised, however, that Elipandus's ideas introduced a poison (venena) to the catholic faith. If unity was an important precondition for salvation, heresy was the internal force that threatened that unity.

29 Beatus of Liébana, Tractus in Apocalipsin, ed. Gryson. Matter, “The Apocalypse in Early Medieval Exegesis,” 38-50; Gil, “Los terrores del ano 6000,” 1. 217-47, 222-238.

30 Alcuin, Epistola, 23, ed. Dümmler, 60-65.

31 Alcuin, Contra haeresim Felicis, 101.230.

32 Alberi, “Like the Army of God's Camp'," 1-20; Garrison, "The Bible and Alcuin's Interpretation of Current Events,” 68-84; Markus, "Living within Sight of the End,” 23-34.

33 A distinction made in Drønen, "Conversion in Context," 209-221, at 212.

34 Capitulare Francofurtense (a. 794), ed. Werminghof, 165.

35 Epistola episcoporum Franciae, ed. Werminghof, 143: in qua [...] salutis nostrae initium extat et finis.

36 The classic statement of unity and diversity in this context it McKitterick, The Frankish Church and the Carolingian Reforms. 
The rhetoric of the Adoptionist Debate, overall, illustrates the problem of apocalyptic insiders and outsiders neatly. We have two groups, who both perceived themselves to be the champions of orthodoxy, both using apocalyptic language to assert their role as the representatives of the sancta ecclesia persecuted by deceitful enemies in the Last Times. In this kind of context, what drove the heightening of language was that both sides claimed the centre ground, and did so from an institutional standpoint. This was a not a fight about the margins and otherness; this was a fight about the corruption of the spiritual heart of the Church. The two sides were united by a common conceptual repertoire but divided by different ways of expressing themselves and the different cultural pressures they faced. As we explore the next case study, the martyrs' movement of Córdoba, we will encounter similar dynamics.

\section{Looking Inwards: The Martyrs of Córdoba}

For the second example, we move to the middle of the ninth century and the city of Cordoba - the capital of Umayyad authority in the West. ${ }^{37}$ The city was the scene of a number of flashpoints between 850 and 859, in which Christians provoked their own martyrdom by verbally attacking Muslim officials and mosques - actions that were intended as much as a challenge to Christian accommodation with Muslims as a challenge to Muslim authority itself. ${ }^{38}$ It should be stressed that not all Christians shared the sense of opposition, and indeed one of the ringleaders was, for a time, imprisoned by Bishop Reccafredus of Seville as the bishop sought to maintain peace. ${ }^{39}$ There was much sensitivity over whether provoking people to kill you really counted as "martyrdom" 40 The sentiments and stories of the martyrs nevertheless appealed to many Franks, and Usuard of Saint-Germain-des-Prés included notices about them in his martyrology for King Charles the Bald (840-877), after visiting the region in $857-858$ but possibly on the basis of stories in southern France. ${ }^{41}$ This is the only obvious case in which millenarianism might help us to understand the provocative actions of individuals involved, if one believed that radical violence on the margins was readily reducible to millenarian impulses. ${ }^{42}$ It remains unprovable whether or not there was any motivation to the "martyrs" themselves beyond oppo-

37 Wolf, Christian Martyrs in Muslim Spain.

38 Patey, “Asserting Difference in Plurality,” 53-66; Gutiérrez, “Los mártires de Córdoba,” 453-463.

39 Albar, Vita Eulogi, 4 and 6, ed. Gil, 332-34.

40 Tolan, “Mahomet et l'antéchrist dans l'Espagne du IXème siècle,” 167-180, at 170. Palmer, “The Frankish Cult of Martyrs and the Case of the two Saints Boniface," 326-348.

41 Usuard, Martyrologium, ed. Dubois. Nelson, "The Franks, the Martyrology of Usuard, and the Martyrs of Córdoba,” 67-80; Christys, “St-Germain des-Prés,” 199-216.

42 Cutler, “The Ninth-Century Martyrs’ Movement,” 329-330. 
sition to another religious-cultural group. ${ }^{43}$ There is, nevertheless, evidence that cultural conflict and apocalyptic narratives affected some Christian self-identification in the period among those who wrote about the "martyrs".

It is, again, worth reflecting on the situation in the Frankish kingdom to highlight some of the moods in play. Religious difference had become re-politicised in the 830 s and 840 s after a series of crises, no doubt intensified by the tensions that clouded the last days of Emperor Louis the Pious's reign (813-840) and led to outright civil war in 840-843. ${ }^{44}$ The headline crisis was the sack of Paris in 845 by pagan Vikings in an attack that prompted reflections on the providential message of Jeremiah at ecclesiastical meetings in Meaux and Paris. ${ }^{45}$ An attack on Rome in 846 by pirates - "Saracens and Moors" (Saraceni Maurique) according to Prudentius of Troyes, not that it is clear how he would know - did not help matters, and indeed generated apocalyptic reflection as far away as Constantinople. ${ }^{46}$ Anti-Jewish sentiment intensified too, stoked by the shock conversion to Judaism of Bodo-Eleazar, who fled to the relative religious diversity of Spain in $838 .{ }^{47}$ Frankish religious culture hardly had a reputation for promoting proto-multiculturalism before all this, and a sense of being under attack by religious others only intensified issues. Many writers turned to prophecy and apocalypse to find ways of conceptualising threats and what they meant for them and their place in the world. ${ }^{48}$ The appeal of the Cordoba martyrs in such a context is unsurprising.

The Córdoba movement is remarkable for the sizeable literature it inspired by close friends Eulogius of Córdoba and Paul Albar. Eulogius used New Testament models to promote a negative view of Islam in order to push for more resistance to it amongst his Christian peers. He drew in particular on Second Thessalonians and the Gospels to cast Muhammad himself as a precursor Antichristi and pseudoprophet. ${ }^{49}$ The Córdoba martyrs were here claimed to be justified in their actions for making a stand against evil when many other people were instead led astray by the seductive words of teachers to be conciliatory. In the Memoriale Sanctorum, addressed to Paul Albar, he opined that the martyrs "seem to me to be true imitators of the apostle Paul, who said 'if anyone preaches to you other than what you have received, let him be anathema' (Galatians 1:9) [...] They come forth against the Angel of Satan and forerunner of Antichrist, professing widely what is holy, which now

43 Wolf, Christian Martyrs in Muslim Spain, 104.

44 Palmer, "The Otherness of Non-Christians in the Early Middle Ages," 40-41.

45 Meaux-Paris, ed. Hartmann 81-84.

46 Annales Bertiniani, ed. Waitz, 34. See also here Lankila, “The Saracen Raid of Rome in 846," 93120 on how the sheer organisation of the raid may have inspired a dramatic reaction among Christians. On the Greek reaction, see Alexander, The Byzantine Apocalyptic Traditions, 77-78.

47 Reiss, "From Aachen to Al-Andalus," 131-57.

48 Palmer, The Apocalypse in the Early Middle Ages, 178-183.

49 Eulogius of Córdoba, Liber apologeticus martyrum, 12-13, ed. Gil, 482-483. Tolan, "Mahomet et l'antéchrist dans l'Espagne du IXème siècle," 174-175. 
indeed the whole Church of Spain preaches with voices, although hidden while oppressed." 50 In the Liber apologeticus martyrum, he wrote "among all the other authors of heresies [...] [Muhammad] created, by the instigation of the devil, a sect of new superstitions and separated himself far from the community of the Holy Church." 51 Such language drove home Eulogius' argument that Islam was a heresy to be resisted by the faithful, as Christians and Muslims fought to claim the upperhand in a shared cosmology. ${ }^{52}$ The nature of the polemic revealed a different reality, of course: that many Christians were happy to make their accommodations. Eulogius was trying to change the opinions of his fellow Christians, not simply to reflect them.

A crucial ingredient here was the representation of Muhammad as another precursor Antichristi. Eulogius quoted verbatim from a Vita Muhammadi, possibly translated from a Greek original, which he had found in Pamplona in the very north of Spain..$^{53}$ The purpose of this biography was to denigrate Muhammad, calling him a "pseudo-prophet" and "heresiarch", before casting aspersions about his sexual morals. It is not apocalyptic except in drawing attention to Muhammad's status as a pseudo-prophet, which establishes an important key to interpretation: this was not perceived as a clash between two different world religions per se, but still rather something conceptualised as a problem with "internal enemies". Muhammad, it was argued, had committed Christian sermons to memory in order to subvert them. In a letter, John of Seville drew Paul Albar's attention to the text but amplified the language a little, so that it referred to "the heretic Muhammad, pseudo-prophet of the Arabs, precursor of Antichrist” (hereticus Arabum pseudoprofetarum sigillus, Antichristi precessor). ${ }^{54}$ As with the first case study, the apocalyptic discourse had its roots in discourse about unity and heresy. Indeed, as Ann Christys has suggested, the whole point of the polemic was to justify the martyrs actions in the face of Christian condemnation, with the attack on Islam designed to bolster the position of Eulogius and Albar in the debate rather than to denigrate Muslims directly. ${ }^{55} \mathrm{By}$ making Muhammad a precursor Antichristi and heresiarch, as Tolan argued, the debate was given "une place claire et comprehensible dans l'histoire et l'eschatologie chré-

50 Eulogius of Córdoba, Memoriale Sanctorum, 1.6, ed. Gil, 375: Ac per hoc veri imitators Pauli apostolic mihi esse videntur, qui ait: Si quis vobis evangelizaverit praetor quod acceptistis, anathema sit. Cuius testimonii informati oraculis, prosiliunt contra angelum Satanae etiam omnis ecclesia Hispaniae quamquam clandestinis ut oppressa praedicat vocibus.

51 Eulogius of Córdoba, Liber apologeticus martyrum, 19, ed. Gil, 487: Denique inter ceteros post ascensionem Domini haeresum auctores solus hic infaustus novae superstitionis sectam instinctu diaboli condens procul ab ecclesiae sanctae convent descitur.

52 Tieszen, "From Invitation to Provocation," 21-33.

53 Wasilewski, "The Life of Muhammad in Eulogius of Córdoba," 333-353; Christys, Christians in alAndalus, 62-68.

54 Paul Albar, Epistulae, 6.8-10, ed. Gil, 200-201. Collins, “Literacy and the Laity,” 109-133, at 121. 55 Christys, Christians in al-Andalus, 68. 
tiennes, tout en justifiant et glorifiant les martyrs qui s'opposent aux suppôts de l'antéchrist". ${ }^{56}$

Paul Albar, who also wrote letters against Bodo-Eleazar, wrote the highly provocative Indiculus luminosus - one part anti-Muslim polemic, one part Gregory the Great-inspired meditation on suffering in Daniel and Job. ${ }^{57}$ Throughout, he talked about "the persecution of Antichrist", clearly referring to the perceived treatment of Christians, but also outlining "Antichrist" as a type of enemy in Christian history in the spirit of classic exegesis on the subject. ${ }^{58}$ Christians themselves could be tainted by willingly adopting the cultural practices of the Muslims, including circumcision. ${ }^{59}$ Rhetorically, picking up on a familiar refrain, anyone who was positioned against Christ was an antichrist. Heresy was crucial to the tapestry of ideas here, as he quoted Jerome: "I consider all heresiarchs to be antichrists; to teach, under the name of Christ, things that are contrary to Christ." 60 This raised the theme of the apocalyptic insider again, by making the perceived persecution of Christians a matter of opposition through internal corruption. Internal corruption could, of course, have external causes, and Paul noted the infections of heresy caused by "doctrines of heretics, philosophers and Jews" (doctrinis hereticorum philosoforum Iudeorumque). ${ }^{61}$ Heresy was poison to the body of the faithful to Paul, just as it had been to the Frankish critics of Adoptionism a generation earlier.

Strikingly, the one element of prediction concerned not the apocalypse per se, but the end of Arab rule in Iberia. This is a subject on which Paul Albar talked about in relation to (pseudo-)ethnic groups more than elsewhere. He built on Jerome associating Antichrist with Little Horn, and talked about how the Greeks and Franks ("under the name of the Romans", sub nomine Romanorum) and the Goths had been laid low. ${ }^{62}$ After "a time and times and a half" (Dan. 7:25; Apoc. 12:14), however, the "kingdom of the people of the Ishamaelites" would come to an end. What could this "time of times" mean? Efforts to interpret the phrase in Pseudo-Methodius' Revelation had led to the prophecy that rule of the Ishmaelites would end after ten weeks of years in the Syrian version of c. 690 (i.e. 70 years) or seven weeks of years in the early-eighth-century Greek and Latin versions (i.e. 48 years). ${ }^{63}$ "Time and times and

56 Tolan, “Mahomet et l'antéchrist dans l'Espagne du IXème siècle,” 180.

57 Paul Albar, Indiculus luminosus, ed. Gil, 270-315. His letters to Bodo-Eleazar are Albari Epistulae 14-20, ed. Gil, 227-270. Kenneth Baxter Wolf, "Muhammad as Antichrist,” 3-19.

58 Paul Albar, Indiculus luminosus, 3-4, 6, 15, 21, 32-35, ed. Gil, 274-277, 278-279, 287, 293-295, 311-315. McGinn, Antichrist, esp. 86.

59 Paul Albar, Indiculus luminosus, 35, ed. Gil, 313; Patey, “Asserting Difference in Plurality,” 57.

60 Paul Albar, Indiculus luminosus, 34, ed. Gil, 313: Ego reor omnes eresiarcas Antichristos esse et sub nomine Christi ea docere que contraria Christo sunt. Jerome, In Evangelium Matthaei, PL 26.176B. 61 Paul Albar, Indiculus luminosus, 27, ed. Gil, 302 (cf PL, 121.543A for the corrected Latin).

62 Paul Albar, Indiculus luminosus, 21, ed. Gil, 294; Jerome, In Danielem, 4.12.7, ed. Glorie, 941. 63 Pseudo-Methodius, 13.2, ed. Reinink, vol. 1, 57 (German translation) and vol. 2, 35 (Syrian); ed. Aerts and Kortekaas, 164 (Greek) and 165 (Latin). On the Syrian version on this point see Reinink, "Pseudo-Methodius," 149-187. For comparison with Paul Albar see Tolan, Saracens, 91. 
a half" was generally understood in the West, following Jerome's commentary, as referring to an approximate $31 / 2$ years of Antichrist's persecution. ${ }^{64}$ It depends, however, where one wanted to interpret the phrase. In the spirit of the Methodian interpretation - coincidentally or not - Paul Albar multiplied $31 / 2$ by 70 to give a length of 245 years for the reign of the Ishmaelites, partly on the basis that they were associated with Antichrist. ${ }^{65}$ Demonstrating a command of dating systems, he gives his present year as A.D. 854, 892 in the Spanish Era, and 240 lunar years or 229 solar years according to the Arab calendar, and then calculates that there are 16 years left of this 245 years. ${ }^{66}$ This projects a hope for liberation into the future in the year 870 . It is left open whether anything more apocalyptic might be expected after that in the vein of Pseudo-Methodius, although the idea of vanquishing the followers of Antichrist would not have been without apocalyptic resonance.

The writings of Eulogius and Paul Albar highlight the complexities of forming Christian identities. For them, there was a clear sense of a defining contrast between Christians and Muslims. Nevertheless, definition was not grounded in religious differences as we would understand them today, with clear doctrinal and theological differences, but rather in the Old Testament anxiety about persecution and related liberation fantasies. It is, again, in many respects like Pseudo-Methodius in this approach to understanding religious difference through a textual lens. Also like Pseudo-Methodius, anxiety was fuelled by debates within Christian communities themselves about acceptable limits of accommodation between different religious groups. With multiple senses of what it meant to be Christian in play, people could appropriate the urgency of fears about heresy with time running short to try to reinforce and define their own position more clearly. In doing so, Eulogius and Albar came closer to contemporary Frankish attitudes than those of many of their contemporaries in Iberia.

\section{Looking Outwards: The Prophetic Chronicle}

The prophecy of Paul Albar's chronicle leads us the third case study and the socalled Chronica Prophetica of 883, most likely written in al-Andalus. ${ }^{67}$ It is less a chronicle and more a collection of genealogies and notes that collectively provided a providential framing for Iberian history. ${ }^{68}$ That history has the Goths and Saracens

64 Jerome, In Danielem, 2.7.25, ed. Glorie, 847.

65 I am not aware of any hard evidence for knowledge of Pseudo-Methodius directly in Spain but Ann Christys has highlighted evidence that suggests similar stories involving a Last World Emperor were in circulation by the eighth century: Christys, Christians in al-Andalus, 47-51.

66 Paul Albar, Indiculus luminosus, 21, ed. Gil, 294.

67 Chronica Prophetica, ed. Bonnaz, 1-9.

68 For a fuller analysis see now Marschner, "The Depiction of the Saracen Foreign Rule in the Prophetic Chronicle through Biblical Knowledge." 
with lineages stretching back to Genesis, making ethnic identity central to the struggle. On account of its manuscript tradition and the use of epitome chronicles and regnal lists, it has been associated with the less providential Chronica Albeldensis of 883; consensus, however, treats that chronicle as a separate, northern work. ${ }^{69}$ The particular context of the prophecy is clear: the author-editor expected Alfonso III of Asturias to reconquer the south imminently, harnessing an eschatological-providential mode to express hopes for political liberation. ${ }^{70}$ The author records the prophecy that Saracen domination would last 170 years - a figure possibly derived from a gematrical reading of the a cloud in Ezekiel 38 - after which "the peace of Christ would be returned to the Holy Church" (pax Christi Ecclesiae Sanctae reddatur).$^{71}$ It is significant here that the author turns the particular situation of the Church in Iberia into a wider issue for the whole Church - a part for the whole - as it highlights the universalising tendencies of Christian identity discourse.

As with Eulogius and Paul Albar earlier in the century, the author of the Chronica Prophetica used engagement with Muslims to frame his polemic. Indeed, a central point for him is that the Muslims themselves (or so he claimed) believed that their domination of Iberia would last only 170 years. ${ }^{72}$ This may connect to a prophecy recounted in the ninth-century history of Ibn Habīb, known through a reworking of 888-891 by his student Yahyā I-Maghāmi, in which the conqueror Mūsā ibn Nusayr (d. 716) predicted the fall of Córdoba within 200 years as part of a series of stories about moral disintegration and the end of time. ${ }^{73}$ Ibn Habīb said that there would be 25 rulers of Córdoba, just as there had been 25 rulers of the Visigoths in Spain - after which, Yahyā I-Maghāmi added, he expected a non-Arab ruler. ${ }^{74}$ The author of the Chronica Prophetica listed 24 rulers up to Muhammad I (r. 852-888), before noting again the expectation of imminent vengeance. ${ }^{75}$ Given the explicit reference to Muslim prophecies, it is unlikely that the parallel is mere coincidence.

The strategy of generating identities through genealogies, lists and fragmentary historical notes was far from novel. It can be found explicitly in cases such as Paul the Deacon's Liber de episcopis Mettensibus, to implicit cases such as the AngloSaxon Chronicle ${ }^{76}$ It was also strong in Arab historiographical traditions in the ninth century. ${ }^{77}$ This connected with a providential way of viewing Gothic history first set

69 Goméz-Moreno, “Las primeras crónicas,” 588. Gil, Chronica Hispana saec. VIII et IX, 212. Gil edits the Chronica Albeldensis at 437-484.

70 Collins, Caliphs and Kings, 54-55. Deswarte, “La prophétie de 883," 39-56, esp. 48-49.

71 Chronica Prophetica, 2.2, ed. Bonnaz, 3. Marschner, "The Depiction of the Saracen Foreign Rule in the Prophetic Chronicle through Biblical Knowledge."

72 Chronica Prophetica, 2.2, ed. Bonnaz, 3.

73 Safran, The Second Umayyad Caliphate, 145-147.

74 Ibn Habīb, Kitab al-ta'rīj, ed. Aguade, 153. Christys, “The History of Ibn Habīb,” 335.

75 Chronica Prophetica, 7, ed. Bonnaz, 8-9.

76 On Paul the Deacon see also Reimitz, “Transformations of Late Antiquity," 279-280. On AngloSaxon tradition see Moisl, “Anglo-Saxon Royal Genealogies and Germanic Oral Tradition,” 215-248. 77 Christys, "The History of Ibn Habīb.” 
out by Isidore of Seville in the seventh century. Writing for the Gothic king Sisenand in 624, Isidore rehabilitated the association between the Goths and their potentially negative association with Gog of Magog. ${ }^{78}$ He referred ambiguously to Ezekiel's prophecy that Gog of Magog would lead a providential scourge on Israel, but he employed it as part of a tapestry of deep historical points that collectively stressed the vitality of the Goths and the weakness of their Roman predecessors. Such a literary strategy came with an interesting apocalyptic pedigree, because Augustine had been forced to deny that the Goths who disrupted the Roman Empire in the fourth and fifth centuries were to be identified with the hordes of Gog and Magog prophesied in Revelation. Isidore was able to defuse this anxiety further by making the one-time apocalyptic outsiders the reformed heirs of Roman dignity.

The strategy of the Chronica Prophetica was to strengthen the prophetic identity of the Goths using Isidore's model. The principal difference was that Isidore had written at a time of Gothic strength, whereas the author of the Chronica Prophetica was writing in the second century after the conquest of 711. The Goths' loss of Spain was blamed squarely on the Goth's own sinfulness, just as the predicted return of the land to them was blamed on the faithlessness of the Muslims. ${ }^{79}$ Although the author claims the authority of Ezekiel's prophecies about Gog for this, the quotations given to not correspond to any of the text in Ezekiel; indeed, the story inverts the narrative, so that Gog is punished and then redeemed, whereas in the Old Testament, Gog is the punishment set upon Israel that is later forced back. In the Chronicle, Gog was no longer the enemy of Israel: typologically, it was Israel. Gog and Magog had been fully rehabilitated through their association with the Goths.

The raises powerful issues about the nature of apocalyptic insiders and outsiders. As it was elsewhere, the Muslims' identity was constructed in relation to Sarah, Hagar and Ishmael, to give a sense that they were not complete outsiders to the faith, but rather people who shared some of the lineage of salvation from which they had become separated. ${ }^{80}$ Muhammad himself was given an important role here by the author, who included a variant version of the Vita Muhammadi with all its talk of a depraved heresiarch to argue for the Muslims' lack of faith. ${ }^{81}$ But again, to place heresy at the heart of Muslim-Christian difference was invoke a sense in which the Muslims could have been insiders, and indeed almost were insiders, because they were subject to the same forces and stories of salvation history. The ambivalence over whether Gog and Magog were attacking peoples or secret enemies within meant that the distinction between insider and outsider was not always clear... except, some would claim, to the careful observer.

78 Isidore of Seville, Historia Gothorum, Wandalorum, Sueborum, ed. Alonso, 172. Palmer, "Apocalyptic Outsiders and their Uses in the Early Medieval West,” 315.

79 Chronica Prophetica, 2.1, ed. Bonnaz, 3.

80 Chronica Prophetica, 3, ed. Bonnaz, 3. Tolan, “'A Wild Man, Whose Hand will Be against All'.”

81 Chronica Prophetica, 4, ed. Bonnaz, 5-6. 


\section{Conclusion}

People define Christian identities fundamentally in relation to the stories and typological patterns of the Old and New Testament. The examples we have encountered above demonstrate different ways in which people could negotiate identities in relation to apocalyptic and related providential concepts. In the first example, longstanding anxieties rooted in Christology debates led to both sides of the Adoptionist Debate meditating on the persecution of the Church and the dangers to unity posed by heresy - an issue closely bound to ideas about Antichrist, because heretics led people astray by proclaiming falsehoods under the banner of Christianity. In the second example, similar core ideas were employed to unsettle accommodation between Christians and Muslims: Islam was portrayed directly as a dangerous heresy associated with Antichrist, and a prophecy of liberation was introduced. In the third example, the issues of heresy and apocalypse were less important, but the providential baggage and the vision of a unified the sancta Ecclesia in peace was to the fore. In each case, identities were framed by ideas rooted in meditations on issues of heresy and prophecy - ideas that often resonated strongly with apocalyptic beliefs and rhetoric.

Perceptions of being on the inside, as part of the sancta Ecclesia, did not necessarily involve access to special knowledge about when the End might come. Indeed, the only explicit prophecy concerned fantasies about the liberation of Christians from Muslim rule in Iberia. To talk in such terms was to enter a related kind of providential discourse, in which one assessed successes and failures in relation to an ongoing tallying of sins and good works. People could lose God's favour and they could win it back. The process of reflecting on this is understood well as part of historiographical tradition and the creation of ethnic identities. The case studies we have encountered expose useful instances in which different peoples in different situations used a shared, universalising repertoire of ideas to redraw their Christian identities and, in the process, blur the religious and ethnic characteristics of those they perceived as different to themselves. At the same time, they illustrate enough variety even within communities in Iberia and Francia to remind us to be careful about the generalisations we might attempt to make about a "Western apocalyptic tradition". The success of apocalyptic discourse often lies in its flexibility. 


\section{Bibliography}

\section{Abbreviations}

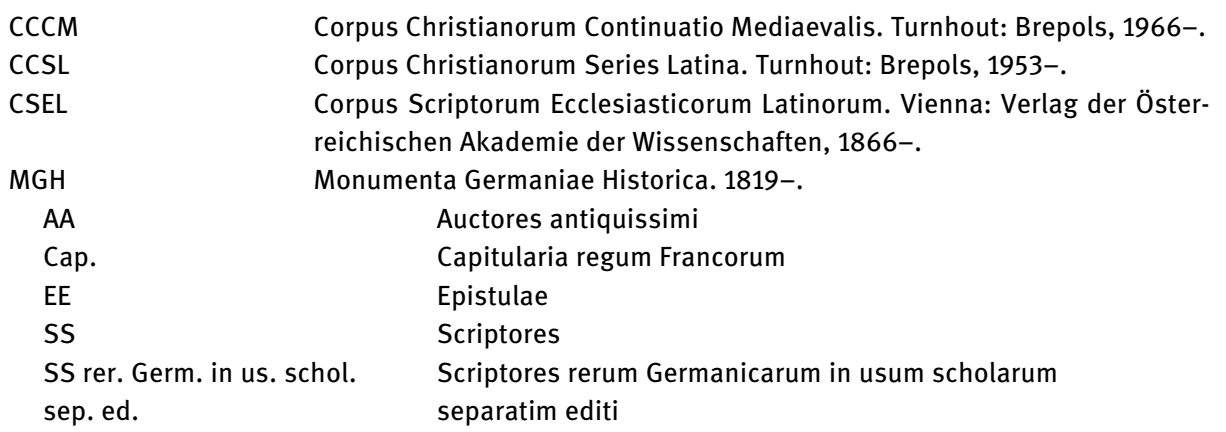

Patrologiae cursus completus, series Latina, ed. Jacques-Paul Migne, 221 vols. Paris, 1844-1855, 1862-1865.

\section{Primary Sources}

Admonitio Generalis. Edited by Hubert Mordek, Klaus Zechiel-Eckes, Michael Glatthaar. MGH Font. iur. Germ. ant. in us. schol. 16, Hannover: Hahn, 2012.

Alcuin. Contra haeresim Felicis. PL 101. Paris: excudebat Vrayer, 1863.

Alcuin. Epistolae. Edited by Ernst Dümmler, MGH EE 4/2. Berlin: Weidmann, 1895.

Annales Bertiniani. Edited by Georg Waitz. MGH SS rer. Germ. in us. schol. sep. ed. 5, Hannover: Hahnsche Buchhandlung, 1883.

Beatus of Liébana. Tractus in Apocalipsin. Edited by Roger Gryson. CC SL 107A. Turnhout: Brepols, 2012.

Beatus of Liébana. and Eterius of Osma. Adversus Elipandum libri duo. Edited by Bengt Löfstedt. CC CM 59. Turnhout: Brepols, 1984.

Capitulare Francofurtense (794). Edited by Albert Werminghof. MGH Concilia 2/1. Hannover: Hahn, 1906.

Chronica Albeldensis. Edited by Juan Gil. CC CM 65. Turnhout: Brepols, 2018.

Chronica Prophetica. Edited by Yves Bonnaz, Chroniques Asturiennes (fin IXe siècle). Paris: CNRS Éditions, 1987.

Elipandus. Epistolae. Edited by Juan Gil, Corpus Scriptorum Muzarabicorum. Consejo Madrid: Superior de Investigaciones Cienfiticas, 1973.

Epistola episcoporum Franciae. Edited by Albert Werminghof. MGH Concilia 2/1. Hahn: Hanover, 1906.

Eulogius of Córdoba. Liber apologeticus martyrum. Edited by Juan Gil, Corpus Scriptorum Muzarabicorum. Madrid: Consejo Superior de Investigaciones Cientificas, 1973.

Eulogius of Córdoba. Memoriale Sanctorum. Edited by Juan Gil, Corpus Scriptorum Muzarabicorum. Madrid: Consejo Superior de Investigaciones Cientificas, 1973.

Ibn Habīb. Kitab al-ta'rijj. Edited by Jorge Aguade. Madrid: Consejo superior de Investigaciones Científicas, 1991.

Isidore of Seville. Etymologiae. Edited by Wallace Lindsay. Oxford: Clarendon Press, 1911. 
Isidore of Seville. Historia Gothorum, Wandalorum, Sueborum ("Las historias de los Godos, Vandalos y Suevos de Isidoro de Sevilla"). Edited by C. Rodríguez Alonso. Léon: Centro de Estudios e Investigación San Isidoro, 1975.

Jerome. In Danielem, edited by Franciscus Glorie. CC SL 75A. Turnhout: Brepols, 1964.

Jerome. In Evangelium Matthaei. PL 26, 176B. Paris: excudebat Vrayer, 1884.

Meaux-Paris. Edited by Wilfrid Hartmann, 81-84. MGH Concilia 3. Hannover: Hahnsche Buchhandlung, 1984.

Paul Albar. Indiculus luminosus. Edited by Juan Gil, Corpus Scriptorum Muzarabicorum. Madrid: Consejo superior de Investigaciones Cientificas, 1973.

Paul Albar. Vita Eulogi. Edited by Juan Gil, Corpus Scriptorum Muzarabicorum. Madrid: Consejo Superior de Investigaciones Cientificas, 1973.

Die syrische Apokalypse des Pseudo-Methodius, 2 vols. Edited by Gerrit Reinink. Louvain: Peeters, 1993; Die Apokalypse des Pseudo-Methodius: die ältesten griechischen und lateinischen Übersetzungen, 2 vols. Edited and translated by W.J. Aerts and G.A.A. Kortekaas. Louvain: Peeters, 1998.

Usuard, Martyrologium. Edited by Jacques Dubois. Brussels: Société des Bollandistes, 1965.

\section{Secondary Literature}

Akbari, Suzanne. Idols in the East: European Representations of Islam and the Orient, 1100-1450. Ithaca: Cornell University Press, 2009.

Alberi, Mary. “'Like the Army of God's Camp'. Political Theology and Apocalyptic Warfare at Charlemagne's Court." Viator 41, no. 2 (2010): 1-20.

Alexander, Paul. J., The Byzantine Apocalyptic Traditions. Berkeley: University of California Press, 1985.

Brandes, Wolfram. "Gog, Magog und die Hunnen: Anmerkungen zur eschatologischen 'Ethnographie' der Völkerwanderungszeit." In Visions of Community in the Post-Roman World, edited by Walter Pohl, Clemens Gantner and Richard Payne, 477-498. Farnham: Ashgate, 2012.

Brown, Peter. The Rise of Western Christendom: Triumph and Diversity. 3rd ed. Oxford: Wiley-Blackwell, 2013.

Cavadini, John C. The Last Christology of the West: Adoptionism in Spain and Gaul, 785-820. Philadelphia: University of Pennsylvania Press, 1993.

Chandler, Cullen. "Heresy and Empire: The Role of the Adoptionist Controversy in Charlemagne's Conquest of the Spanish March." The International History Review 24, no. 3 (2002): 505-527.

Cohn, Norman. The Pursuit of the Millennium: Revolutionary Millenarians and Mystical Anarchists of the Middle Ages. New York: Oxford University Press, 1957.

Christys, Ann. "St-Germain des-Prés, St Vincent and the Martyrs of Córdoba." Early Medieval Europe 7, no. 2 (1998): 199-216.

Christys, Ann. Christians in al-Andalus (711-1000). Richmond: Curzon Press, 2002.

Christys, Ann. "The History of Ḥabīb and Ethnogenesis in al-Andalus." In The Construction of Communities in the Early Middle Ages: Texts, Resources and Artefacts, edited by Richard Corradini, Max Diesenberger and Helmut Reimitz, 323-348. Leiden: Brill, 2003.

Clarke, Nicola. The Muslim Conquest of Iberia: Medieval Arabic Narratives. London: Routledge, 2012.

Close, Florence. Uniformiser la foi pour unifer l'Empire. La pensée politico-théologique de Charlemagne. Brussels: Académie royale des Sciences, des Letters et des Beaux-Arts de Belgique, 2011.

Collins, Roger. The Arab Conquest of Spain: 710-797. Oxford: Blackwell, 1989. 
Collins, Roger. "Literacy and the Laity in Early Medieval Spain." In The Uses of Literacy in Early Medieval Europe, edited by Rosamond McKitterick, 109-133. Cambridge: Cambridge University Press, 1990.

Collins, Roger. Caliphs and Kings: Spain, 796-1031. Chichester: Wiley-Blackwell, 2012.

Cutler, Allan. "The Ninth-Century Martyrs' Movement and the Origins of Western Christian Missions to the Muslims." The Muslim World 55, no. 4 (1965) 321-339.

Deswarte, Thomas. "La prophétie de 883 dans le royaume d'Oviedo: attente adventiste ou espoir d'une liberation politique?" In Millénaire et millénarisme: les mythes de la chrétienté, 39-56. Mélanges de Science Religieuse. Lille: Université Catholique de Lille, 2001.

Drønen, Tomas Sundes. "Conversion in Context: Anthropological and Missiological Aspects from African Studies." In The Introduction of Christianity into the Early Medieval Insular World, edited Roy Flechner and Máire Ní Mhaonaigh, 209-221. Turnhout: Brepols, 2016.

Garrison, Mary. "The Franks as the New Israel? Education for an Identity from Pippin to Charlemagne." In The Uses of the Past in the Early Middle Ages, edited by Yitzhk Hen and Matthew Innes, 141-161. Cambridge: Cambridge University Press, 2000.

Garrison, Mary. “The Bible and Alcuin's Interpretation of Current Events." Peritia 16 (2002): 68-84. Geary, Patrick. "Ethnic Identity as a Situational Construct in the Early Middle Ages." Mitteilungen der anthropologischen Gesellschaft in Wien 113 (1983): 15-26, reprinted in: Writing History: Identity, Conflict, and Memory in the Middle Ages, edited by Florin Curta and Cristina Spinei, 1-18. Bucharest: Editura Academiei Române, 2012.

Gil, Juan. "Los terrores del ano 6000." In Actas del simposio para el estudio de los codices del "Comentario al apocalypsis' de Beato de Liebana, 217-247. Madrid: Joyas Bibliothgráfias, 1978.

Goetz, Hans-Werner. Die Wahrnehmung anderer Religionen und christlich-abendländisches Selbstverständnis im frühen und hohen Mittelalter (5.-12. Jahrhundert), 2 vols. Berlin: Akademie Verlag, 2013.

Goméz-Moreno, Manuel, “Las primeras crónicas de la Reconquista. El ciclo de Alfonso III.” In Boletín de la Real Academia de la Historia 100 (1932): 562-628.

Jong, Mayke de. "Charlemagne's Church." In Charlemagne. Empire and Society, edited by Joanna Story, 103-135. Manchester: Manchester University Press, 2005.

Jong, Mayke de. "The State of the Church and Early Medieval State Formation." In Der frühmittelalterliche Staat - europäische Perspektiven, edited by Walter Pohl and Veronika Wieser, 214254. Vienna: Österreichische Akademie der Wissenschaften, 2009.

Kramer, Rutger. "Adopt, Adapt and Improve. Dealing with the Adoptionist Controversy at the Court of Charlemagne." In Religious Franks: Religion and Power in the Frankish Kingdoms - Studies in Honour of Mayke de Jong, edited by Rob Meens, Dorine van Espelo, Bram van den Hoven van Genderen, Janneke Raajmakers, Irene van Renswoude and Carine van Rhijn, 32-50. Manchester: Manchester University Press, 2016.

Landes, Richard. Heaven on Earth: The Variety of Millennial Experience. Oxford: Oxford University Press, 2011.

Lankila, Tommi P., "The Saracen Raid of Rome in 846: An Example of Maritime ghazw," in Travelling Through Time: Essays in Honour of Kaj Öhrnberg, edited by Sylvia Akar, Jaakko Hämeen-Anttila and Inka Nokso-Koivisto, 93-120. Helsinki: Societas Orientalis Fennica, 2013.

Lapiedra Gutiérrez, Eva. "Los mártires de Córdoba y la política anticristiana contemporánea en Oriente." Al-Qantara 15, no. 2 (1994) 453-463.

Matter, E. Ann. "The Apocalypse in Early Medieval Exegesis." In The Apocalypse in the Middle Ages, edited Richard Emmerson and Bernard McGinn, 38-50. Ithaca, NY: Cornell University Press, 1992. 
Matter, E. Ann. “Orthodoxy and Deviance.” In Cambridge History of Christianity, vol. 3: Early Medieval Christianities, c. $600-$ c. 1100, edited by Thomas F.X. Noble and Julia M.H. Smith, 510530. Cambridge: Cambridge University Press, 2008.

McGinn, Bernard. Antichrist: Two Thousand Years of the Human Fascination with Evil. San Francisco: Harper, 1994.

McKitterick, Rosamond. The Frankish Church and the Carolingian Reforms, 789-895. London: Royal Historical Society, 1977.

Markus, Robert A. “Living Within Sight of the End." In Time in the Medieval World, edited by Chris Humphrey and William Mark Ormrod, 23-34. York: York Medieval Press, 2001.

Marschner, Patrick S. "The Depiction of the Saracen Foreign Rule in the Prophetic Chronicle through Biblical Knowledge,” Journal of Transcultural Medieval Studies 5 (2018): 215-240.

Meier, Mischa. "Eschatologie und Kommunikation im 6. Jahrhundert n. Chr. - oder: Wie Osten und Westen beständig aneinander vorbeiredeten." In Endzeiten. Eschatologie in den monotheistischen Weltreligionen, edited by Wolfram Brandes and Felicitas Schmieder, 41-73. Berlin, New York: De Gruyter, 2008.

Moisl, Hermann. “Anglo-Saxon Royal Genealogies and Germanic Oral Tradition.” Journal of Medieval History 7 (1981): 215-248.

Nelson, Janet L. "The Franks, the Martyrology of Usuard, and the Martyrs of Córdoba." Studies in Church History 30 (1993): 67-80.

O’Leary, Stephen. Arguing the Apocalypse: a Theory of Millennial Rhetoric. Oxford: Oxford University Press, 1994.

Palmer, James T. "The Frankish Cult of Martyrs and the Case of the two Saints Boniface." Revue Bénédictine 114, no. 3-4 (2004): 326-348.

Palmer, James T. The Apocalypse in the Early Middle Ages. Cambridge: Cambridge University Press, 2014.

Palmer, James T. "The Otherness of Non-Christians in the Early Middle Ages." Studies in Church History 51 (2015) 33-52.

Palmer, James T. “Apocalyptic Outsiders and Their Uses in the Early Medieval West." In Peoples of the Apocalypse: Eschatological Beliefs and Political Scenarios, edited by Wolfram Brandes, Felicitas Schmieder, Rebekka Voß, 307-320. Berlin: De Gruyter 2016.

Patey, Ariana. “Asserting Difference in Plurality: The Case of the Martyrs of Córdoba." Studies in Church History 30 (2015): 53-66.

Pohl, Walter. "Christian and Barbarian Identities in the Early Medieval West: Introduction." In PostRoman Transitions: Christian and Barbarian Identities in the Early Medieval West, edited by Walter Pohl, Gerda Heydemann, 1-46. Turnhout: Brepols, 2013.

Pohl, Walter and Gerda Heydemann, eds. Strategies of Identification. Ethnicity and Religion in Early Medieval Europe. Turnhout: Brepols, 2013.

Pohl, Walter and Helmut Reimitz, eds. Strategies of Distinction: The Construction of Ethnic Communities, 300-800. Leiden: Brill, 1998.

Reimitz, Helmut. History, Frankish Identity, and the Framing of Western Ethnicity, 550-850. Cambridge: Cambridge University Press, 2014.

Reimitz, Helmut. "Transformations of Late Antiquity: The Writing and Re-Writing of Church History at the Monastery of Lorsch, c. 800." In Resources of the Past in Early Medieval Europe, edited by Clemens Gantner, Rosamond McKitterick and Sven Meeder, 262-282. Cambridge: Cambridge University Press, 2016.

Reinink Gerrit. "Pseudo-Methodius: A Concept of History in Response to the Rise of Islam." In The Byzantine and Early Islamic East: Problems in the Literary Source Material, edited by Averil Cameron and Lawrence I. Conrad, 149-187. Vol. 1, Studies in Late Antiquity and Early Islam. Princeton: The Darwin Press 1992. 
Reiss, Frank. "From Aachen to Al-Andalus: The Journey of Deacon Bodo (823-876)." Early Medieval Europe 13, no. 2 (2005): 131-157.

Safran, Janina. The Second Umayyad Caliphate: the Articulation of Caliphal Legitimacy in al-Andalus. Cambridge/ Mass.: Harvard University Press, 2000.

Tieszen, Charles L. “From Invitation to Provocation: 'Holy Cruelty' as Christian Mission in NinthCentury Córdoba." Al-Masaq 24, no. 1 (2012): 21-33.

Tolan, John. "Mahomet et l'antéchrist dans l'Espagne du IXème siècle." In Orient und Okzident in der Kultur des Mittelalters, edited by Danielle Buschinger and Wolfgang Spiewok, 167-180. Greifswald: Reineke-Verlag, 1997.

Tolan, John. Saracens: Islam in the Medieval European Imagination. New York: Columbia University Press, 2002.

Tolan, John. “'A Wild Man, Whose Hand Will Be Against All': Saracens and Ishmaelites in Latin Ethnographical Traditions, from Jerome to Bede." In Visions of Community in the Post-Roman World, edited by Walter Pohl, Clemens Gantner and Richard Payne, 513-530. Farnham: Ashgate, 2012.

Valenzuela, Claudia. "The Faith of the Saracens. Forms of Knowledge of Islam in the Christian Kingdoms of the Iberian Peninsula until the 12th Century." Millennium - Jahrbuch 10 (2013): 311-330.

Wasilewski, Janna. "The Life of Muhammad in Eulogius of Córdoba: Some Evidence for the Transmission of a Greek Polemic in the Latin West." Early Medieval Europe 16, no. 3 (2008): 333353.

Wickham, Chris. "Problems in Doing Comparative History." In Challenging the Boundaries of Medieval History: The Legacy of Timothy Reuter, ed. Patricia Skinner, 5-28. Turnhout: Brepols, 2009.

Wieser, Veronika. "Roms wilde Völker: Grenzüberschreitungen und Untergangsstimm(ung)en im letzten Jahrhundert des römischen Imperiums." In Peoples of the Apocalypse: Eschatological Beliefs and Political Scenarios, edited by Wolfram Brandes, Felicitas Schmieder, Rebekka Vo $\beta$, 23-50. Berlin: De Gruyter 2016.

Wolf, Kenneth Baxter. Christian Martyrs in Muslim Spain. Cambridge: Cambridge University Press, 1988.

Wolf, Kenneth Baxter. "Muhammad as Antichrist in Ninth-Century Cordoba." In Medieval and Early Modern Spain: Interaction and Cultural Change, edited by Mark D. Meyerson and Edward D. English, 3-19. Notre Dame: University of Notre Dame Press, 1999. 